\title{
PELATIHAN BAGI GURU-GURU SD N 3 MARGOYOSO DALAM MENGGUNAAN GOOGLE CLASROOM Nurmitasari Nurmitasari ${ }^{1}$, Ainur Rosidah ${ }^{2}$, Naning Sutriningsih ${ }^{3}$ \\ ${ }^{1,2,3}$ FKIP, Universitas Muhammadiyah Pringsewu \\ Email : nurmitasari@umpri.ac.id ${ }^{1}$
}

\begin{abstract}
Abstrak : Tujuan dari kegiatan pengabdian kepada masyarakat ini adalah untuk memberikan pelatihan kepada guru-guru SD N 3 Margoyoso kabupaten Tanggamus dalam menggunakan google classroom melalui android maupun laptop. Kegiatan ini dilaksanakan di salah satu ruang kelas di SD N 3 Margoyoso yang dihadiri oleh 12 orang peserta yang tergabung dalam sivitas akademika SD N 3 Margoyoso. Tahapan yang dilakukan dalam kegiatan ini adalahan tahap perencanaan dan tahap pelaksanaan. Tahap perencanaan yaitu melakukan analisis situasi untuk mengetahui permasalahan yang dialami sekolah mitra dan merancang materi kegiatan pelatihan yakni terkait google classroom. Tahap pelaksanaan terdiri dari kegiatan penyampaian materi tentang google classroom dan kegiatan pelatihan praktek penggunaan google classroom. Hasil dari kegiatan ini adalah guru-guru di SD N 3 Margoyoso mengetahui adanya aplikasi yang dapat membantu pelaksanaan pembelajaran daring khususnya google classroom dan dapat mengaplikasikannya dalam pembelajaran daring.
\end{abstract}

Kata Kunci : Pelatihan, Google Classroom, Pembelajaran Daring

\section{Pendahuluan}

Pandemi covid-19 merupakan virus yang mewabah di Indonesia. Penularan virus covid-19 ini melalui sentuhan baik itu sentuhan tangan maupun sentuhan air liur yang di keluarkan manusia saat bersin. Untuk itu salah satu kebijakan pemerintah Indonesia untuk menekan penyebaran penularan virus covid ini adalah dengan menaati protocol kesehatan. Protocol kesehatan tersebut yaitu mencuci tangan dengan sabun, memakai masker, menghindari kerumunan, dan menjaga jarak aman. Kebijakan ini memberikan dampak yang begitu besar di sector Pendidikan. Pelaksanaan Pendidikan di Indonesia beralih dari yang tadinya pembelajaran tatap muka secara langsung menjadi pembelajaran daring.

Pembelajaran daring dipilih sebagai alternatif pembelajaran jarak jauh untuk mengurangi potensi penyebaran virus. Pembelajaran daring adalah pembelajaran yang dilakukan secara online menggunakan aplikasi pembelajaran maupun jejaring social. Pembelajaran daring ini dilaksanakan sesuai dengan Surat Edaran Menteri Pendidikan dan Kebudayaan Republik Indonesia nomor 3 Tahun 2020 tanggal 9 Maret 2020 tentang pencegahan covid-19 pada satuan Pendidikan. Pembelajaran daring ini menuntut guru disetiap jenjang Pendidikan untuk dapat beradaptasi dengan teknologi. Hal ini dikarenakan pembelajaran daring ini melibatkan aplikasi untuk mendukung lancarnya pelaksanaan pembelajaran. Aplikasi tersebut meliputi google classroom, google meet, zoom, webex, WhatsApp, Ruang guru, Portal Rumah Belajar, Youtube, dan masih banyak lainnya. Aplikasi yang paling familiar pada guru-guru adalah aplikasi WhatsApp. Permasalahan pembelajaran daring yang terjadi di SD N 3 Margoyoso adalah guru hanya mengandalkan aplikasi WhatsApp grup saja. Penggunaan WhatsApp grup yakni sekedar untuk mengshare tugas. Kemudian siswa mengumpulkan tugas yang sudah diselesaikan satu minggu sekali kesekolah. Hal ini membuat tugas-tugas siswa menumpuk dan bercecer. Ditambah lagi jika siswa tidak lengkap mengumpulkan tugasnya pada setiap mata pelajaran sehingga diakhir semester siswa memiliki hutang tugas yang belum diselesaikan sangat banyak. Hal ini tidaklah efisien.

Berdasarkan observasi melalui mahasiswa yang tergabung dalam program kampus mengajar yang bertempatan di SD N 3 Margoyoso ditemukan alasan mengapa guru-guru SD N 3 Margoyoso tidak menggunakan aplikasi-aplikasi yang mendukung pembelajaran daring. Alasannya yaitu kurangnya pemahaman dan cara penggunaan aplikasi-aplikasi tersebut. Sehingga tujuan dari kegiatan ini adalah memberikan pelatihan kepada guru-guru SD N 3 Margoyoso dalam menggunakan aplikasi-aplikasi yang mendukung pembelajaran daring khususnya google classroom. Google clasroom merupakan sebuah aplikasi pembelajaran online yang dapat digunakan secara gratis dan bisa membuat kelas mereka sendiri hanya dengan membagikan kode kelas atau mengundang mahasiswa untuk bergabung dalam kelas 


\section{(2) BAGIMU NEGERI : JURNAL PENGABDIAN MASYARAKAT \\ P-ISSN : 2548-8651 | E-ISSN : 2548-866X \\ Email : ejournal@umpri.ac.id}

google clasroom seperti yang diungkap oleh (Wardhi, 2020). Berdasarkan penelitian yang dilakukan oleh Cech dan Bures (2004), suksesnya implementasi pembelajaran online membutuhkan tiga hal utama yaitu people, processes dan technology. People disini berkaitan dengan kemampuan siswa, perilaku siswa maupun guru dalam menggunakan google Classroom. Process berkaitan dengan implementasi google Classroom dalam melakukan pembelajaran. Technology berkaitan dengan ketersediaan infrastruktur untuk menggunakan google classroom. Kelebihan dari google classroom menurut Paksi dan Ariyanti (2020) yaitu (1) mobile friendly, orang yang baru pertama kali menggunkan google classroom pati tidak mengalami kesulitan dalam menggunkannyakarena google sendiri sangat memperhatikan kenyamanan pengguna; (2) pengelolaan tugas yang mudah, saat guru atau admin memberikan tugas pada siswa, dengan mudahnya siswa bisa melihat pada satu halaman penyedia tugas sehingga tidak akan merepotkan siswa dalam mencari tugas; (3) file google classroom disimpan digoogle drive semua file dalam bentuk mp4, $\mathrm{mp} 3$, doc, pdf, zip dan lain-lain. Semua file tersebut secara otomatis masuk ke google drive; (4) paperless, system online dapat mengurangi penggunaan kelas artinya sudah membantu pelestarian lingkungan alam.

Adapun manfaat dari kegiatan ini adalah memberikan pengetahuan dan pelatihan kepada guruguru SD N 3 margoyoso terkait tentang google classroom sehingga guru-guru SD mampu mengoperasikan aplikasi google classroom. Selain lain itu kegiatan ini diharapkan dapat memberikan kontribusi dalam mengefektifkan kegiatan pembelajaran secara daring di SD N 3 Margoyoso. Bagi Jurusan Pendidikan Matematika dan Pendidikan Guru Sekolah Dasar STKIP Muhammadiyah Pringsewu Lampung kegiatan ini merupakan bentuk pengabdian kepada masyarakat yang merupakan salah satu misi dari Catur Dharma Perguruan Tinggi yang diharapkan dapat mengasah kemampuan para dosen dalam melaksanakan pengabdian sesuai dengan bidang yang ditekuninya.

\section{Metode}

Metode pelaksanaan pengabdian kepada masyarakat ini dilaksanakan sebagai bentuk upaya dalam memberikan solusi permasalahan yang dirasakan oleh guru-guru SD N 3 Margoyoso dalam pembelajaran daring. Kegiatan pelatihan ini dilaksanakan bekerjasama dengan mahasiswa yang sedang melaksanakan kegiatan Merdeka Belajar Kampus Merdeka (MBKM) pada program kampus mengajar. Peserta dalam kegiatan pelatihan ini yaitu seluruh sivitas akademika SD N 3 Margoyoso yang meliputi guru kelas, guru mata pelajaran (PAI dan Penjaskes), kepala sekolah, wakil kepala sekolah dan operator sekolah sebanyak 12 orang. Tahapan yang dilakukan dalam kegiatan pelatihan ini, yakni: perencanaan dan pelaksanaan. Tahap perencanaan dimulai dari mempelajari permasalahan yang dihadapi oleh guruguru SD N 3 Margoyoso dalam melaksanakan pembelajaran daring. Tahap perencanaan dilanjutkan dengan merancang pelaksanaan kegiatan pelatihan yakni dengan menggunakan aplikasi zoom. Karena aplikasi zoom belum familiar bagi guru-guru SD N 3 Margoyoso maka untuk pelaksanaan nantinya akan dibantu oleh mahasiswa kampus mengajar yang bertempatan di SD 3 Margoyoso. Selanjutnya menyiapkan materi untuk pelaksanaan kegiatan pelatihan. Tahap pelaksanaan berisikan kegiatan berupa penyampaian materi dan praktik penggunaan google classroom oleh peserta pelatihan. Pada kegiatan penyampaian materi diselingi dengan sesi tanya jawab antara pemateri dengan peserta, kemudian peserta melakukan praktek penggunaan google classroom baik melalui android maupun melalui laptop. Pada proses praktek peserta didampingi oleh pemateri dan tim pelatihan secara virtual serta mahasiswa secara langsung di tempat.

\section{Hasil Dan Pembahasan}

Berdasarkan hasil observasi mahasiswa yang terlibat dalam kampus mengajar pada kegiatan MBKM diperoleh data bahwa pelaksanaan pembelajaran daring di SD N 3 Margoyoso masih manual yakni dengan mengambil tugas di sekolah kemudian dikumpulkan kembali ke sekolah. Adapun aplikasi yang digunakan hanyalah whatsApp grup. Akibatnya membuat tugas siswa banyak dan menumpuk bahkan bercecer. Kemudian siswa tidak pernah tatap muka dalam pelaksanaan pembelajaran. 


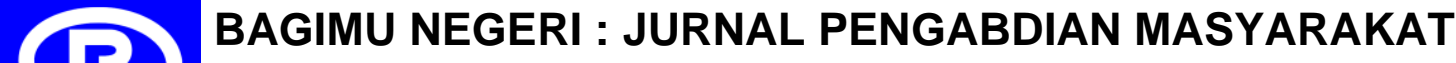 \\ P-ISSN : 2548-8651 | E-ISSN : 2548-866X \\ Email : ejournal@umpri.ac.id}

Dampaknya siswa lebih banyak bermain dibandingkan belajar. Kondisi ini menumbuhkan rasa peduli dosen Pendidikan matematika FKIP UMPRI yang secara kebetulan sebagai dosen pembimbing lapangan kegiatan kampus mengajar program MBKM untuk memberikan pelatihan tentang aplikasi yang dapat digunakan untuk mendukung pembelajaran daring khususnya aplikasi google classroom. Menurut Hapsari dan Pamungka (2019) Google Classroom merupakan sarana memperlancar komunikasi jarak jauh antara pengajar dan pelajar. Seperti yang kita ketahui bersama bahwa pengertian dari pembelajaran daring adalah pembelajaran seperti layaknya dilaksanakan oleh guru kepada peserta didiknya hanya saja tidak bertatap muka secara langsung, namun melalui jaringan internet yang berbantuan dengan aplikasi dalam melaksanakan kegiatan pembelajaran. Sejalan dengan Kemendikbud (2020:6) yang menyatakan bahwa pembelajaran jarak jauh secara daring adalah pembelajaran jarak jauh yang cara pengantaran bahan ajar dan interaksinya dilakukan dengan perantara teknologi internet. Sehingga tatap muka pun bisa dilakukan secara virtual. Langkah berikutnya pada tahap perencanaan adalah membuat materi pelatihan yaitu penggunaan google classroom.

Pelaksanaan kegiatan pelatihan penggunaan google classroom di SD N 3 Margoyoso dilaksanakan pada hari Kamis 3 Juni 2021. Pada sesi penyampaian materi, materi tentang penggunaan google classroom disampaikan oleh Nurmitasari melalui aplikasi zoom. Adapun materi yang disampaikan meliputi pengertian dari google classroom, pengertian dan manfaat dari fitur-fitur yang ada dalam google classroom, kemudian cara menggunakan google classroom yang meliputi: cara membuat akun, cara membuka aplikasi melalui gmail, cara membuat kelas, cara berdiskusi, cara membuat absen, cara membuat tugas, cara mengupload materi, cara mengundang siswa, cara mengundang guru sebagai tim pengajar, cara mengumpulkan tugas dalam satu topik, serta cara berkomunikasi secara langsung/ tatap muka melalui google classroom.

Sabran \& Sabara, E(2018) Google classroom adalah aplikasi yang dibuat oleh google yang bertujuan untuk membantu dosen dan peserta didik apabila kedua hal tersebut berhalangan, mengorganisasi kelas serta berkomunikasi dengan peserta didik tanpa harus terikat dengan jadwal kuliah di kelas. Menurut Yuliani, dkk (2020:79-80) aktivitas yang bisa dilakukan seorang pendidik pada google classroom adalah memberikan pengumuman, menyajikan materi, melakukan absebsi, memberika tugas, membuat kuis, melakukan ujian, memberikan penilaian. Menurut Iftakhar (2016) menyatakan bahwa dengan menggunakan google classroom guru dapat mengontrol bahkan lebih dari satu kelas sekaligus, lebih mudah memberikan pengumuman tentang pelajaran, memudahkan akses siswa dan guru, waktu yang dimiliki guru dan siswa dalam berkomunikasi lebih banyak, bisa mengirim tugas (file atau vidio). Adapun kekurangan dari google classroom Paksi \& Ariyanti, L (2020:14) adalah membutuhkan gawai, tersambung dengan internet, tidak dapat berkomunikasi dengan verbal. Adapun fitur yang terdapat pada google classroom yang dapat dimanfaatkan oleh guru seperti assigments, grading, communication, timecost, archive course, mobile applications, dan privacy (Wicaksono \& Rachmadyanti, 2017)

Pada saat penyampaian materi pelatihan diselingi dengan sesi tanya jawab. Pada kegiatan ini tim pengabdian yang terdiri dari Nurmitasari, Ainur Rosidah, dan Naning Sutriningsih bersama-sama dalam menjawab pertanya dari peserta pengabdian secara beragantian. Rasa ingin tahu peserta pengabdiab terkait materi pelatihan sangatlah besar. Hal ini ditunjukkan dengan banyaknya guru yang bertanya pada sesi ini. Berikut gambar antusias peserta pelatihan dalam kegiatan penyampaian materi dan sesi tanya.
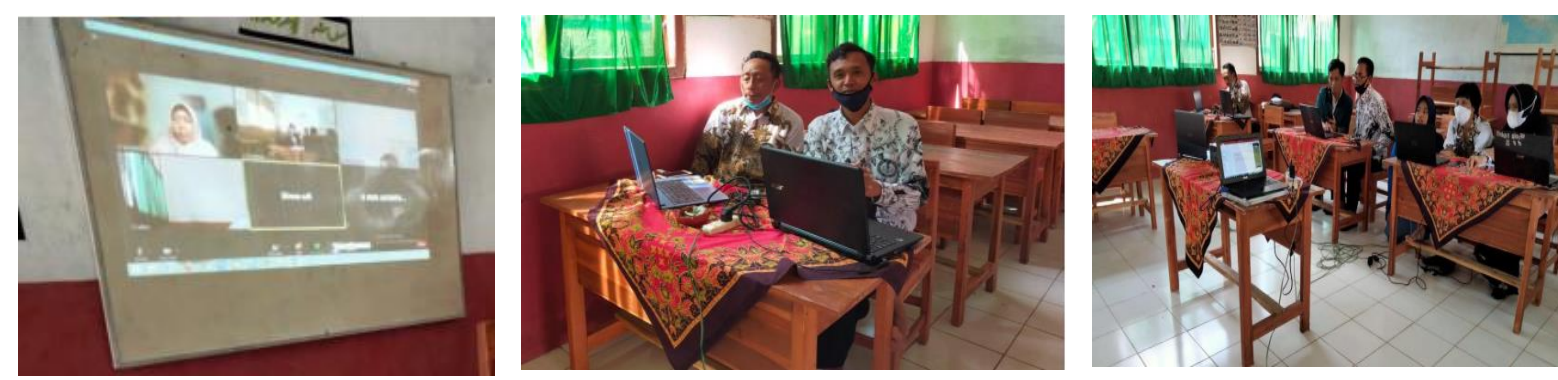

Gambar 1. Penyampaian materi dan sesi tanya jawab 


\section{(2) BAGIMU NEGERI : JURNAL PENGABDIAN MASYARAKAT \\ P-ISSN : 2548-8651 | E-ISSN : 2548-866X \\ Email : ejournal@umpri.ac.id}

Setelah selesai dalam menyampaikan materi kegiatan berikutnya adalah melakukan pelatihan kepada guru-guru SD N 3 Margoyoso untuk langsung praktek menggunakan aplikasi google classroom yang dibantu oleh mahasiswa yang tergabung dalam kegiatan kampus mengajar program MBKM yaitu Dimas Adi Putra dari Universitas Lampung, Sri Wahyuni dari Universitas Muhammadiyah Pringsewu, dan Alfia dari Universitas Islam Indonesia Yogyakarta, serta tim pengabdian yang membimbing dan mengarahkan melalui zoom meeting. Berikut gambar kegiatan praktek langsung penggunaan aplikasi google classroom peserta pelatihan.
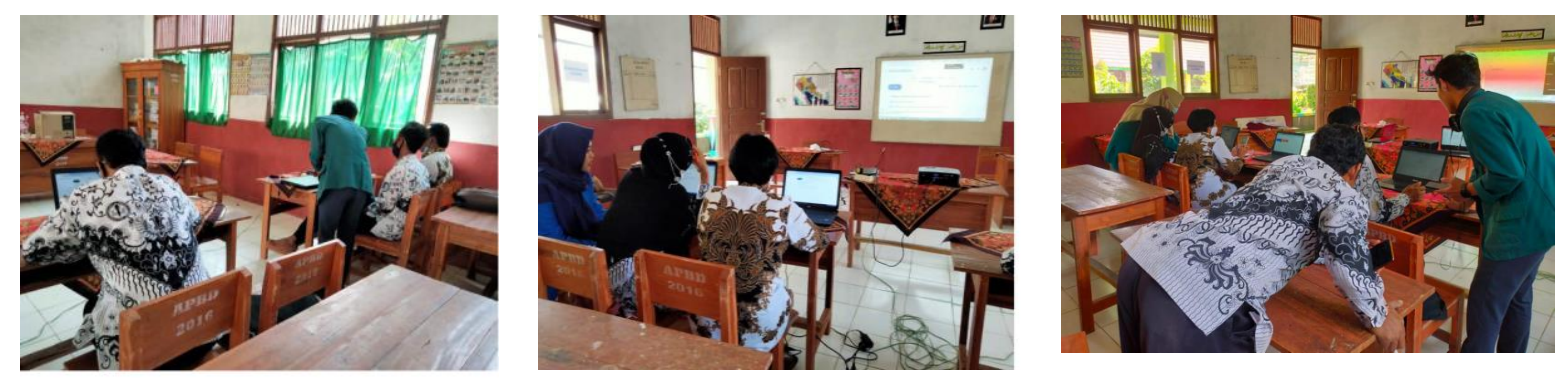

Gambar 2. Gambar saat praktek penggunaan google classroom peserta pelatihan

Dalam praktek pelaksanaan penggunaan google classroom peserta pelaksanaan sangat antusias dalam mengikuti kegiatan. Dengan pendampingan dari mahasiswa kampus mengajar yang bertempatan di SD N 3 Margoyoso peserta pelatihan sangat terbantu sehingga dapat membuat mempunyai kelas pada aplikasi google classroom. Peserta pelatihan dapat menggunakan fitur-fitur yang ada dalam google classroom. Akhirnya mampu menggunakan google classroom dalam pembelajaran daring.

Berdasarkan pelaksanaan kegiatan pelatihan penggunaan google classroom diperoleh hasil yaitu (1) peserta pengabdian memiliki pengetahuan tentang google classroom dan fitur-fiturnya; (2) peserta pengabdian memiliki akun google classroom yang sudah terdapat ruang kelas di dalamnya; dan (3) peserta pengabdian mampu mengoperasikan/menggunakan google classroom untuk mendukung pembelajaran daring. Hasil pengabdian ini sejalan dengan Soni, dkk (2018) yaitu bertambahnya pengetahuan guru-guru SMK Negeri 1 Bangkinang tentang penggunaan google classroom sebagai media pembelajaran meminimalisir penggunaan kertas dalam proses kegiatan belajar mengajar.

Adapun kendala yang dihadapi saat pelaksanaan kegiatan pengabdian kepada masyarakat ini adalah jaringan internet yang kurang baik sehingga membuat suara pemateri saat zoom terputus-putus, dalam pelaksanaan praktek maka menggunakan tethering dengan $\mathrm{Hp}$ peserta masing-masing dikarenakan sekolah belum memasang WIFI sehingga bagi guru yang membeli kuota unlimited maka jaringannya kurang bagus mengakibatkan berkali-kali loding dalam membuka aplikasinya.

\section{Simpulan Dan Saran}

Simpulan dari kegiatan pengabdian kepada masyarakat yang berbentuk pelatihan dengan judul pelatihan guru-guru SD N 3 Margoyoso dalam menggunakan google classroom adalah memiliki pengetahuan tentang google classroom dan fitur-fiturnya, memiliki akun google classroom, dan mampu mengoperasikan/menggunakan google classroom untuk mendukung pembelajaran daring. Kemudian Dari hasil pelaksanaan kegiatan pengabdian masyarakat dapat disampaikan beberapa saran yaitu (1) sebaiknya guru-guru lebih mengembangkan keterampilannya dalam mempelajari aplikasi-aplikasi lain yang dapat mendukung pembelajaran daring seperti zoom, modle, youtube dan lain sebaigainya; dan (2) sebaiknya ada tindak lanjut dari SD N 3 Margoyoso dalam bentuk pelatihan kepada siswanya dengan mengutamakan siswa kelas tinggi untuk mengetahui dan memahami serta bisa menggunakan aplikasi ghoogle classroom sehingga pembelajaran daring selanjutnya dapat berjalan secara efektif. 


\section{(D) BAGIMU NEGERI : JURNAL PENGABDIAN MASYARAKAT \\ P-ISSN : 2548-8651 | E-ISSN : 2548-866X \\ Email : ejournal@umpri.ac.id}

\section{Daftar Rujukan}

Cech dan Bures (2004). E-Learning implementation at University. Proceedings of 3rd European Conference on e-Learning, Paris, France.

Hapsari, S. A. dan Pamungkas, H. (2020). Pemanfaatan Google Classroom Sebagai Media Pembelajaran Online Di Universitas Dian Nuswantoro. WACANA Jurnal Ilmiah Ilmu Komunikasi. Vol. 18 No. 2.

Iftakhar, S. (2016). Google Classroom: What Works and How?. J. Educ. Soc. Sci., vol. 3,

Paksi,H,P \& Ariyanti, L, (2020). Sekolah Dalam Jaringan. Surabaya: Scopindo Media Pustaka

Sabran \& Sabara, E. (2018). Keefektifan google classroom sebagai media pembelajaran. In Prosiding Seminar Nasional Lembaga Penelitian Universitas Negeri Makassar "Diseminasi Hasil Penelitian Melalui Optimalisasi Sinta dan Hak Kekayaan Intelektual

Soni, dkk. (2019). Optimalisasi Pemanfaatan Google Classroom Sebagai Media Pembelajaran DI SMK Negeri 1 Bangkinang. Jurnal Pengabdian Untuk Mu NegeRI, Vol.2 No.1.

Tim Penyusun. (2020). Booklet Pembelajaran Daring. Direktorat Jenderal Pendidikan Tinggi Kemdikbud RI.

Wardhi, R. Y. (2020). Respon Mahasiswa terhadap Pembelajaran Online Melalui Google Classroom. Jurnal Biogenerasi. Vol. 5. No. 2

Wicaksono, V. D., \& Rachmadyanti, P. (2017). Pembelajaran Blended Learning Melalui Google Classroom Di Sekolah Dasar. Diseminarkan pada Seminar Nasional Pendidikan PGSD UMS \& HDPGSDI Wilayah Jawa pada 17 Mei 2017.

Yuliani, M. dkk, (2020). Pembelajaran Daring Untuk Pendidikan: Teori \& Terapan. Yayasan Kita Menulis 